\title{
sciendo
}

CIVIL AND ENVIRONMENTAL ENGINEERING REPORTS

E-ISSN 2450-8594

CEER 2020; 30 (4): 0102-0110

DOI: $10.2478 /$ ceer-2020-0053

Original Research Article

\section{VECTOR OF THE INTELLIGENT OFFICE BUILDINGS FORMATION}

\author{
Kristina GOLUB ${ }^{1}$ \\ ${ }^{1}$ Kyiv National University of Construction and Architecture, Kyiv, Ukraine
}

\begin{abstract}
Every day the architecture expands its borders and opportunities. In meeting the challenges of commercial office buildings designing, which include not only the aesthetic and functional aspects, the efficiency problem of their exploitation becomes more actual, including resource conservation, energy efficiency, environmental friendliness, environmental protection, safety (the fire, terrorism, natural disaster, etc.), comfortable working conditions, reduced operating expenses and economy. The regulatory and legal framework that ensures the development of intelligent buildings (IBs) and the establishment of automatic control systems in office buildings in the USA, Europe and Asia are analysed in the article. Based on the trends of the office buildings development, the main influencing factors of the automated control systems on the formation of intellectual and administrative buildings are identified and based on which a new vector of digital, dynamic and transformative architecture is selected.
\end{abstract}

Keywords: intelligent buildings, building management systems, office buildings, artificial intelligence, secure architecture, transformative architecture

\footnotetext{
${ }^{1}$ Corresponding author: Kyiv National University of Construction and Architecture, Ukraine, e-mail: golub.kv@knuba.edu.ua
} 


\section{INTRODUCTION}

At different stages of civilization development the concept of "technology" defined the path leading to future progress, and the rate of change of technology is directly proportional to the speed of progress. The concepts "smart phone", "smart watch", «smart car" and so on have become common for us. And the word "intelligence" is now used not only to describe the mental faculties of human, but in a new context - to describe the buildings, cars, computers, and various portable gadgets; this concept is better known as "artificial intelligence." The impact of artificial intelligence on comfort, safety and energy saving of building requires more detailed researching, taking into account the role of information technology as the basis of the socio-economic transformation in society.

The basis of this intelligence is the building management system (BMS), otherwise known as building automation system (BAS) - an automated control system installed in buildings, which regulates and controls the mechanical and electrical equipment, ventilation, lighting, power systems, fire extinguishing systems and security systems consisting of software and hardware [2].

\section{MATERIALS AND METHODS}

The important moment, reflecting global trends in developing of automation systems and building management is standardization - regulatory framework that ensures the development of intelligent buildings. There Directive 2012/27/EU of the European Parliament and of the Council on energy efficiency is operated in Europe of 25 October 2012, which defines the basic principles of state policy in this area; in particular, provides the new requirements for the reconstruction of buildings, improving the efficiency of the energy system, energy audit, increasing efficiency heating systems etc [5].

According to the Directive on the energy performance of buildings issued by the European Union, the special standards were developed for main engineering systems: heating - DIN EN 15316-1; EN 15316-3 and EN 15316-4; cooling - DIN EN 15243; ventilation - DIN EN 15241, BSI - BS EN 15243; lighting - DIN EN 15193. The German Institute for Standardization has developed a new European standard DIN EN 15232 " Energy performance of buildings - Impact of Building Automation, Controls and Building Management." It gives the assess of buildings quality in energy efficiency and identifies four classes of energy performance of automation systems: A - high energy performance, B - advanced, C - standard, D - non-energy-efficient [5].

The issues of management systems and designing of intelligent buildings have been researched by Albert Ting-pat So \& Wai Lok Chan [2], that study has based on more detailed analysis of history of development of Building Automation 
Systems (BAS); Mervi Himanen (2003); Derek Clements-Croome (2006) etc. Architects (companies) that were among the first who started to design intelligent office buildings: Richard Keating with Skidmore, Owings \& Merill; Norman Foster with Foster + Partners; RSP Architects, Planners \& Engineers; AHR; Nikken Sekkei; Renzo Piano and others $[2,3,4,9]$.

\section{RESULTS}

It should be noted that the idea of formation a building management system first appeared more after World War II, when the desire to improve comfort inside the buildings has led to more complex mechanical systems, and a tendency to increase the size of buildings was one of the main factors that contributed to the implementation of this concept.

Since the 50s of the XX for the first time, such items of building management systems as: "Reasonable accurate pneumatic sensors \& Controllers" and the first "electronic and electric control systems" were used. In the 60 years the first computerized control centre of building automation was used; electronic control evolved to multiplex control systems that rapidly evolved into head end computers and quickly gave way to mini computers [2].

The first "oil shock" in 1973 gave impetus to break the old energy-intensive and resource consuming model of industrial production, which ensured the prosperity of the Western world in the early post-war decades. Faced with the instability of oil supplies, the Europe was forced to begin big structural economy reforms; to increase investment in the development of advanced technologies, capable to reduce energy consumption and limit the growing dependence on oil imports, resulting the use of mini-computers or central processors in building automation systems have been sharply increased. Energy experts point out that up to $14 \%$ of the global energy consumption is spent in operating buildings and there is trend that the percentage will continue to increase. Reform of the global economy, which was carried out through concerted efforts of leading countries actually became the defining challenge of foreign policy of the second half of 1970 [23]. Since the 80 s, the introduction of personal computers (PCs) has revolutionized in the management industry. Intelligent Buildings Institute (IBI) for the first time formulated the definition of «intelligent building» as "one which provides a productive and cost-effective environment through optimization of four basic elements: structure, systems, services and management, and the interrelationship between them." [4,25]. Already the world's first intelligent building was opened in 1984 in Hartford - a 38-story office centre (height: $163.7 \mathrm{~m}$ ), which was called "City Place" area of $111484 \mathrm{~m}^{2}\left(1200000 \mathrm{ft}^{2}\right)$ and was the tallest commercial structure in Connecticut, USA (cf. Fig. 1a) [16]. It was designed by Skidmore, Owings \& Merrill. In addition to office space, there were various restaurant and 
retail establishments found on the lower floors. All services were orchestrated by a computer system and linked by a fiber-optic network [25].

a) City Place in Hartford (1984) [15]

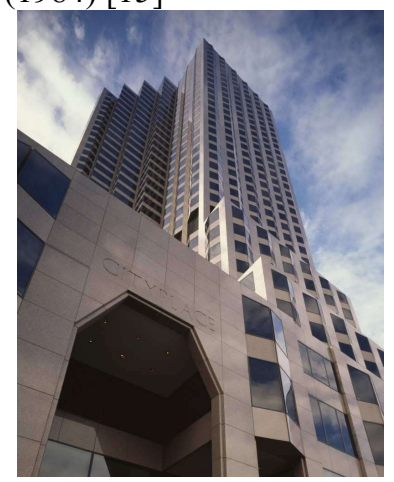

b) Tower 49 in New York (1985) [20]

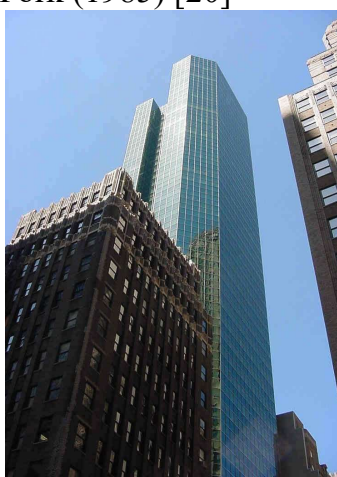

c) LTV Center in Dallas (1985) [16]

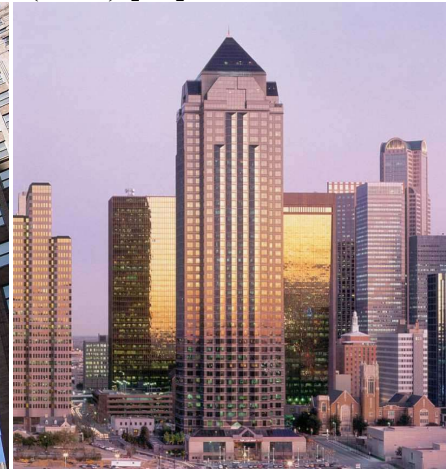

Fig. 1. The First Intelligent Buildings in USA (Arch. Skidmore, Owings \& Merrill)

The following year, the United Technologies Corporation has finished the work on the first intellectual building in New York - "Tower 49" (cf. Fig. 1b). In 1985, the commercial office building was constructed in the Southwest in Dallas (USA) designed by architect Richard Keating of SOM Skidmore, Owings \& Merrill "LTV Center", height 209 m [25] (cf. Fig. 1c).

In Asia one of the first the concept of intelligent building was taken by Japan and built office building "Toshiba HQ" (height: $165 \mathrm{~m} / 40$ floors) with a total area of $147000 \mathrm{~m}^{2}$, which construction was completed in 1984 (cf. Fig. 2a). Another one of the first most high-tech buildings consider the HSBC bank was built in 1985 in Hong Kong and designed by British architect Norman Foster (height: 178.8m /44 floors) with a total area of $99000 \mathrm{~m}^{2}$ (cf. Fig. 2b). The building was built using lightweight constructions that hang on the frame and facilitate internal reorganization and modernization. Designed several 10-story atriums have improved inside air circulation, allowing to save on complex ventilation system. The main way of connection inside the skyscraper, excepting 28 elevators, were the system of 62 escalators linking levels within the atrium $[6,8,21,25]$.

The first administrative building in Singapore with using IBMS was "Capital Tower" designed by architects RSP Architects, Planners \& Engineers and opened in 2000 (height: $254 \mathrm{~m} / 52$ floors) (cf. Fig. 2c). Tenant of the building is Government of Singapore Investment Corporation and also office space of China Club with exclusive bar, restaurant with separate dining and conference rooms only for club members [22]. 
a)

b)

c)

d)

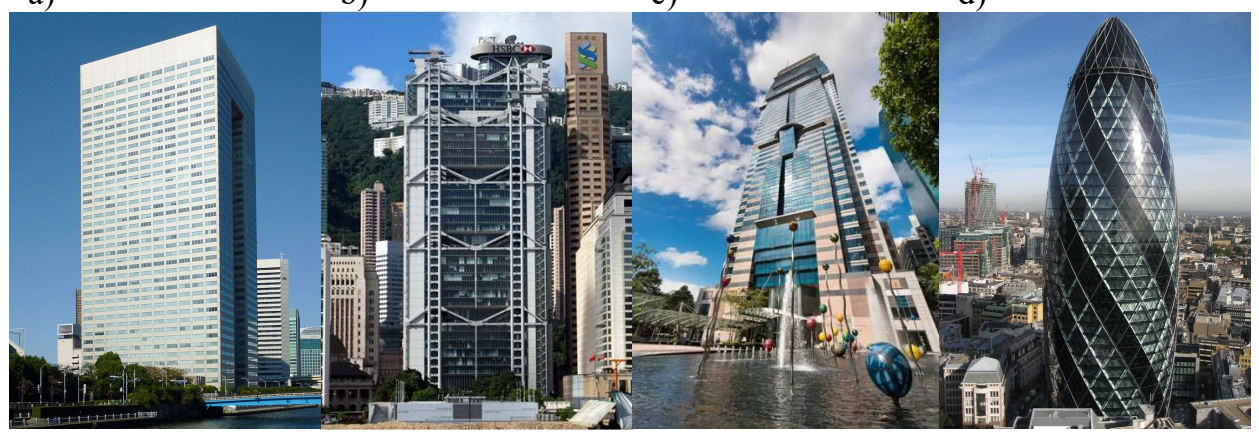

Fig. 2. First Intelligent Buildings in Asia and Europe. a) Toshiba HQ in Tokyo, Japan (1984) [19], b) Bank HSBC in Hong Kong (Norman Foster, 1985) [13], c) Capital Tower in Singapore (RSP Architects, Planners \& Engineers, 2000) [14], d) 30 St. Mary Axe in London, UK (Foster + Partners, 2003) [12]

One of the building feature is highly intelligent parking management system by calculating in real time, where drivers are guided via wall mounted display and as a result - a driver saves time and fuel consumption. Among other technologies of this building should be noted exhaust fans that are activated in the carparks when the carbon monoxide sensors register more than 1,000 parts per million; escalators that are slowed down if not in use; 35 passenger elevators are equipped with dual LCD panels, which provide news in real time; since 2008 the Capital Tower has been using NeWater for many of its non-domestic purposes: irrigation systems for landscape areas, air-conditioning and fire protection. The NeWater is being delivered to these systems via a separate piping system approved by the authorities [22].

Another striking example of the building high performance is 30 St. Mary Axe in London designed by Foster+Partners in which was managed to reduce energy consumption by half via the form of the building, saving interior space, the organization of which makes the building energy efficient (cf. Fig. 2d). Each floor is shifted a few degrees, creating so-called "lungs" that allow air to circulate between the floors of the building not giving too warming up in summer and, conversely, protecting it in winter not preventing to natural light [7].

One of the newly constructed buildings in London is "The Shard" of italian architect Renzo Piano has asymmetrical shape height of $310 \mathrm{~m}$, which recycles waste and generates a significant share of used energy (cf. Fig. 3a). The building is insulated by double façade with an air bag; sensors monitors lighting and automatically changes the amount of light penetrating inside; rainwater is collected and used again for climate control and other needs. Due the fortified core 
the skyscraper has to withstand a collision with airliner and any natural disaster [11].

a)

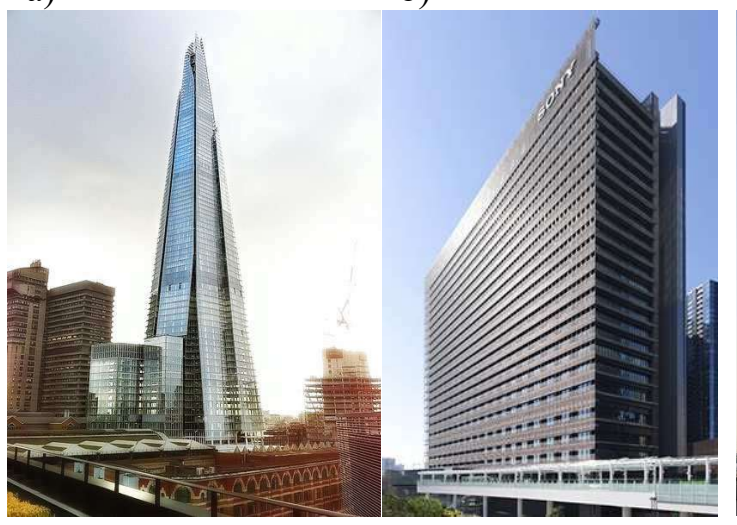

c)

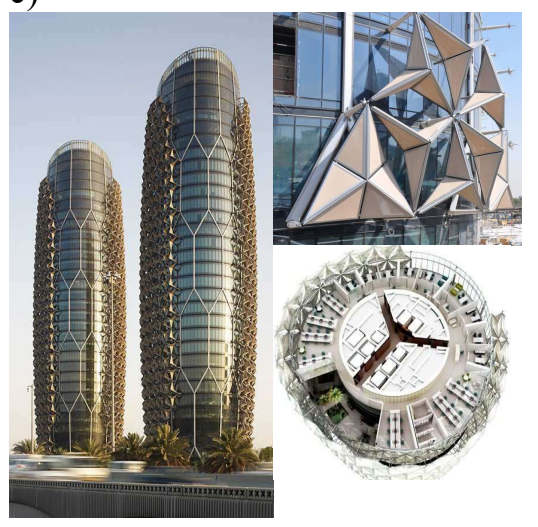

Fig. 3. The examples of intelligent buildings constructed in 2012. a) The Shard in London, UK (Arch. Renzo Piano) [18], b) Sony City Osaki in Tokyo, Japan (Arch. Nikken Sekkei) [17], c) Al Bahr Towers in Abu Dhabi, UAE (Arch. AHR (formerly Aedas UK) [1]

The famous Al Bahr Towers in Abu Dhabi designed by AHR (formerly Aedas UK) and constructed by Al-Futtaim Carillion (height : 145m) using motifs of traditional architecture have the moving facades depending on the light to protect the inside space from the 50 degree heat (cf. Fig. 3c). The degree of the mashrabiya opening is defined by computer from a fully open state in the morning to complete closing at noon [1].

Designed by Nikken Sekkei the NBF Osaki Building (Formerly Sony City Osaki) is not especially noticeable skyscraper, but at the same time is one of the most unusual of intelligent buildings - the solar panels are situated on the southern facade; rainwater is collected on the roof, and the inside planning is organized in a way that employees will be suffered less from heat of the day (cf. Fig. 3b). The eastern facade of the building is a huge evaporator is covered with specialized ceramic louvers that guide rainwater through the system to act as enormous radiator for cooling the environment. If you want to slow down the evaporation, a tube is being closed by shutters. Unlike other systems of microclimate, here the excess heat is not thrown outside; the pipes system requires no electricity and cools not only the building but also mitigates climate a few quarters [24]. 


\section{DISCUSSION}

The necessity to reduce energy consumption, efficient use of resources and trends in automated control systems testify about a new vector of development of administrative buildings. The problem of searching effective ways to overcome the possible negative consequences during exploitation of buildings contributed to the development of intelligent systems that reduce the human factor; human is included to the management system as a necessary operational link, the load on who is being decreased with increasing the degree of management process automation. There are forms of process control that require frequent human action, and the control form in which the actions of the operator bears episodic character and its main task is reduced to monitoring indications and maintaining of constant readiness to intervene if necessary in the management of the object. Intelligent building differs from automated, primarily the ability to program the control system so that the reaction to the events in and around the perimeter of the building will take place according to the predetermined scenario. Any subsystems of such building are functioned completely autonomously, fixing their actions in the event register or operatively are interacted with the operator, asking him to confirm the actions. Except savings, efficiency, use the alternative energy sources, fire safety and security access, the automated control system opened possibilities for the architects to create a new digital, dynamic and transformative architecture, which in the past was not available (cf. Fig. 4) [3,21].

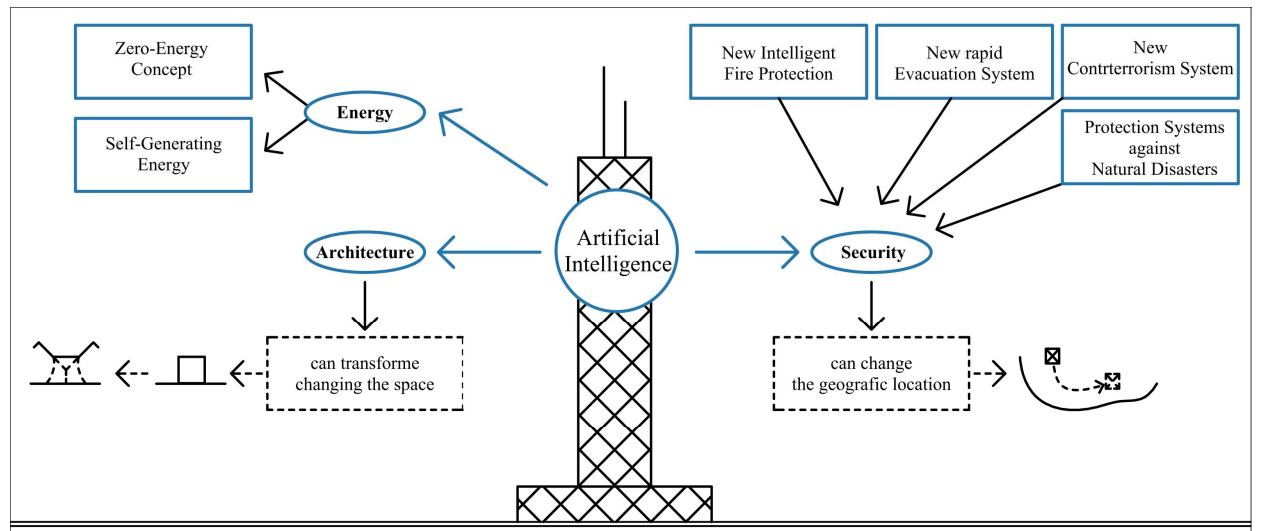

Fig. 4. Author's proposal of additional possibilities of future of intelligent office buildings. Source: Kristina Golub, 2020

\section{CONCLUSIONS}

The aforecited technologies are only an transitional point in the development of intelligent building management systems (IBMS). Today, they are not able 
answering to all challenges and tasks put by modern society. According to the author, the intelligent building should be completely autonomous unit that could be transformed for needs of its consumers, changing its architectural image. Taking into consideration the current trends of formation of intelligent office buildings using automatic control systems it should be noted that in addition to the such problems as lower operating costs, fire safety, security, environmental, etc., buildings do not include protection from natural disasters such as earthquakes, tsunamis, avalanches, mudflows, volcanic eruptions because the constructive methods cannot protect $100 \%$, but unambiguously could be assured by intelligent control system. Since the nature disasters are not systematic formation, so the only intelligent systems can detect such problems early, to analyze and identify the best solutions minimizing the human factor. In particular, the seismological sensors in case of weak earthquake could not only find them, but also influence on the rigidity of structures and subject to strong seismic activity the buildings could change their geographical location. Today it sounds futuristically, but it is one of the tasks of architects-scientists to give the idea which should be the buildings of the future and together with engineers, programmers and other professionals find the way of its implementation.

\section{REFERENCES}

1. AHR Global. Al Bahr Towers, https://bit.ly/35UKsqx, access 15.01.2020.

2. Ting-Pat So, A and Lok Chan, W 1999. Intelligent Building Systems. Springer, 175.

3. Clements-Croome, DJ 2004. Intelligent Buildings: Design, Management And Operation. London: Thomas Telford, 424.

4. Clements-Croome, DJ and Derek, T 1997. What Do We Mean By Intelligent Buildings? Automation in Construction 6(5-6), 395-400.

5. Directive 2012/27/EU of the European Parliament and of the Council on Energy Efficiency.

6. Foster and Partners. Hongkong and Shanghai Bank Headquarters. www.shorturl.at/aciJN, access 10.12.2019.

7. Foster and Partners. St. Mary Axe https://bit.ly/31PzDLU, access 19.01.2020.

8. Harrison, A Loe, E Read, J 1998. Intelligent Buildings in South East Asia. Taylor \& Francis Group, London, 192.

9. Himanen, M 2003. The Intelligence of Intelligent Buildings: the Feasibility of the Intelligent Building Concept in Office Buildings. Espoo: VTT Publications, 492.

10. Madden, R. 1984. Office Growth Changing the Face of Hartford. The New York Times, www.shorturl.at/rsBI2, access 18.10.2020. 
11. O'Hagan, S 2012. Renzo Piano: 'The Shard is my dream building' www.shorturl.at/pHLY1, access 19.01.2020.

12. 30 St. Mary Axe Building in London, www.shorturl.at/ajAC0, access 03.02.2018.

13. Bank HSBC Building in Hong Kong, www.shorturl.at/uyGX5, access 23.01.2018.

14. Capital Tower in Singapore. www.shorturl.at/ixRXY, access 03.02.2018.

15. City Place Building in Hartford. www.shorturl.at/bxL15, access 23.11.2018.

16. LTV Center Building in Dallas, www.shorturl.at/ftzR9, access 23.01.2018.

17. Sony City Osaki Building in Tokyo. www.shorturl.at/koyWX, access 28.07.2018.

18. The Shard Building in London by Bjmullan. www.shorturl.at/BEFG7, access 28.07.2018.

19. Toshiba HQ Building in Tokyo, www.shorturl.at/goyOY, access 23.01.2018.

20. Tower 49, www.shorturl.at/sCLM7, access 23.01.2018.

21. Rubin A 1991. Intelligent Building Technology in Japan. Gaithersburg, Md.: U.S. Dept. of Commerce, National Institute of Standards, 68.

22. RSP Architects, Planners \& Engineers. Capital Tower. www.shorturl.at/crAY2, access 10.12.2019.

23. Show-Ling Wen, Chiang-Pi Hsiao and Ching-Tzu Chen 2009. Intelligent Buildings. In: F. Haghighat and Jong-Jin Kim (ed) Sustainable Built Environment. Encyclopaedia of Life Support Systems Vol. 1, 209-225.

24. Welch, A 2019. Sony City Osaki, Japan: Tokyo Office. E-architect. www.shorturl.at/lpyG3, access 15.01.2020.

25. Wigginton M and Harris J 2002. Intelligent Skins. Oxford: Architectural Press, 184.

Editor received the manuscript: 07.10.2020 